\title{
Catalase enzyme in mitochondria of Saccharomyces cerevisiae
}

\author{
Ventsislava Yankova Petrova \\ Department of Cytology, Histology and Embryology \\ Biological Faculty \\ Sofia University "St. Kliment Ohridski" \\ 8 Dragan Tzankov Blvd., Sofia 1421, Bulgaria \\ Tel: 35926330277 \\ E-mail: petrova_v@ hotmail.com \\ Tanya Vassileva Rasheva \\ Department of General and Industrial Microbiology \\ Biological Faculty \\ Sofia University "St. Kliment Ohridski" \\ 8 Dragan Tzankov Blvd., Sofia 1421, Bulgaria \\ Tel: 35926330277 \\ E-mail: rasheva@biofac.uni-sofia.bg \\ Anna V. Kujumdzieva* \\ Sofia University "St. Kliment Ohridski" \\ Department of General and Industrial Microbiology \\ 8 Dragan Tzankov Blvd., Sofia 1421, Bulgaria \\ Tel: 3592668619 \\ Fax: 3592668619 \\ E-mail: kujumdzieva@biofac.uni-sofia.bg
}

Keywords: catalase, mitochondria, Saccharomyces cerevisiae, SOD.

Abbreviations: SOD: superoxide dismutase; DAB - 3,3': diaminobenzidine tetrachloride; mt: mitochondrial; MW: molecular weight.

Catalase and superoxide dismutase activities have been explored in the yeast Saccharomyces cerevisiae during batchwise growth experiment. During the diauxic growth in YPD medium high Ys values were obtained $(0.415-0.423)$ and correlation between the total activities of both enzymes has been found. A mitochondrial fraction from three type strains of Saccharomyces cerevisiae has been isolated. The purity of this fraction was proved through different enzyme assays: hexokinase, glucose-6-phosphate dehydrogenase, D-amino acid oxidase, isocitric lyase, succinate dehydrogenase. Then the catalase, peroxidase, Mn and $\mathrm{Cu} / \mathrm{Zn}$ superoxide dismutase activities were evaluated in the mitochondrial fraction. Polyacrylamide gel electrophoresis separations allowed to identify a mitochondrial catalase as a band of $0.239 \mathrm{Rm}$ value. It differed from the two catalase specific bands with $\mathbf{R m}$ values 0.218 and 0.257 obtained from the crude extract. It was proved that the three catalase proteins are charge isomers. A positive correlation between the activity of mitochondrial catalase and Mn superoxide dismutase also takes place. Molecular weight of mitochonrial catalase protein has been determined as $240 \mathrm{kD}$.

Catalase is an essential enzyme in the decomposition of intracellular hydrogen peroxide $\left(\mathrm{H}_{2} \mathrm{O}_{2}\right)$. In Saccharomyces cerevisiae cells, two different types of catalase have been found (Traczyk et al. 1985; Skoneczny and Rytka, 2000), which were designated catalase type A and catalase type T
(Seah et al. 1973). The two enzymes are encoded by different genes (CTA1 and CTT1 respectively), possessing independent control and being localized in different compartments: catalase $\mathrm{T}$ is a cytoplasm enzyme whereas catalase $\mathrm{A}$ is localized in peroxisomes (Lapinskas et al. 1993). The molecular weights of the biologically active, homotetrameric enzymes are 170-190 kD and 225-250 kD for catalase A and T respectively (Klei et al. 1990).

Studies with wild type Saccharomyces cerevisiae in continuous cultures on mixture of glucose and $\mathrm{H}_{2} \mathrm{O}_{2}$ indicated an enhanced level of mitochondrial cytochrome $\mathrm{c}$ peroxidase (Verduyn et al. 1988). These results suggested that mitochondria possess an independent mechanism for decomposition of exogenous $\mathrm{H}_{2} \mathrm{O}_{2}$ (Jamieson, 1995). They are also site of endogenous $\mathrm{O}_{2}^{-}$production via autooxidation of ubisemiquinone and electron transport proteins and $\mathrm{H}_{2} \mathrm{O}_{2}$ formed by its spontaneous or enzymatic dismutation (Estruch, 2000; Kowaltowski et al. 2001). The scavenge of these reactive oxygen species is realized by mitochondrial antioxidant system, represented by $\mathrm{Mn}$ containing superoxide dismutase, $\mathrm{Cu} / \mathrm{Zn}$ one found in the intermembrane space of the mitochondria (Ravindranath and Fridovich, 1975; Sturtz et al. 2001) and cytochrom c peroxidase (Charizanis et al. 1999). This well known mechanism for detoxification was added by Scandalios et al. 1980 who proved the presence of catalase enzyme in mitochondria of mesophyll cells of Nicotiana sylvestris and Radi et al. 1991 - in rat heart mitochondria. This evidence

* Corresponding autor 
motivated investigations for presence of catalase in yeast mitochondria, besides of well known cytochrom c peroxidase degrading hydrogen peroxide. It could be expected that such kind of co-operative action of the abovementioned $\mathrm{H}_{2} \mathrm{O}_{2}$ degrading enzymes is also possible.

These observations directed us to investigate mitochondria for the presence of catalase activity in three different strains of Saccharomyces cerevisiae. Our results clearly indicated that a mitochondrial catalase enzyme is present in vivo and suggested the existence of an additional cellular compartment for localization of this protein in yeast cell.

\section{Materials and Methods}

\section{Strains and growth conditions}

The following strains of Saccharomyces cerevisiae obtained from the National Bank for Industrial Microorganisms and Cell Cultures (http://nbimcc.cablebg.net/) were used: NBIMCC 582, NBIMCC 583 and NBIMCC 584. Cells were grown on a rotor shaker $(204 \mathrm{rpm})$ at $30^{\circ} \mathrm{C}$ on standard liquid YPD medium (2\% Glucose, $1 \%$ Yeast extract and 1\% BactoPeptone).

\section{Preparation of cell-free extracts}

Cells from $6,12,48$ and $72 \mathrm{~h}$ of cultivation were harvested by centrifugation at $800 \mathrm{xg}$ for 10 minutes and washed twice with distilled $\mathrm{H}_{2} \mathrm{O}$. Cell wall disruption was carried out by zymolyase according to the procedure of Defontaine et al. 1991. The cell debris was removed by centrifugation at $1000 \mathrm{x} \mathrm{g}$ for $10 \mathrm{~min}$. Then the cell free extracts were frozen and thawed 3 times in order to disrupt mitochondria and centrifuged at $15000 \times \mathrm{g}$ for $10 \mathrm{~min}$. Obtained supernatants were used for enzymatic analyses.

\section{Isolation of mitochondrial fraction}

The fraction of heavy mitochondria was isolated from obtained spheroplasts after osmotic shock in distilled water applying the procedure of Holtta, 1977. The cell debris was harvested at $1000 \mathrm{x} \mathrm{g}$ for $10 \mathrm{~min}$ and the heavy mitochondrial fraction was isolated by centrifugation at $3500 \mathrm{x} \mathrm{g}$ for $20 \mathrm{~min}$. Then the crude mitochondrial pellet was carefully washed with buffer, containing $0.5 \mathrm{M}$ sorbitol, $50 \mathrm{mM}$ Tris, $10 \mathrm{mM}$ EDTA, $\mathrm{pH}$ 7.5. This procedure was repeated three times and collected mitochondria were resuspended in desionized water and lysed by freezing and thawing. The obtained sample of disrupted mitochondria was subjected to further biochemical analyses.

\section{Enzyme assays}

All enzyme assays were performed in cell-free extracts as well as in mitochondrial fractions.
Catalase [EC: 1.11.1.6] activity was determined spectrophotometrically according to Aebi, 1970. One unit of enzyme activity was expressed as D E/min/mg protein.

Peroxidase [EC: 1.11 .1 .7$]$ activity was assayed by the $3,3^{\prime}-$ diaminobenzidine tetrachloride [DAB] method of Selander et al. 1986. One unit of enzyme activity was expressed as D $\mathrm{E} / \mathrm{min} / \mathrm{mg}$ protein.

Superoxide-dismutase [EC: 1.15 .1 .1$]$ activity was measured as described by Beauchamp and Fridovich, 1971. One unit was defined as the amount of enzyme causing 50\% decrease in the reduction of Nitro Blue Tetrazolium (NBT). The $\mathrm{Mn}$ - containing type of the enzyme was proved by inhibition analysis with $2 \mathrm{mM} \mathrm{KCN}$ (Geller and Winge, 1984).

The succinate dehydrogenase [1.3.99.1] activity in mitochondrial fraction was determined by the method of Bonner, 1955. One unit of enzyme activity was expressed as mol reduced $\mathrm{K}_{3} \mathrm{Fe}(\mathrm{CN})_{6} / \mathrm{min} / \mathrm{mg}$ protein.

Hexokinase [2.7.1.1] activity in cell-free extract and mitochondrial fraction was defined according to Greene, 1969. One unit of enzyme activity was expressed as $\mathrm{mol} / \mathrm{min} / \mathrm{mg}$ protein.

Glucose-6-phosphate dehydrogenase [1.1.1.49] activity was determined by the method of Greene, 1969. One unit of enzyme activity was expressed as mmol reduced $\mathrm{NADP} / \mathrm{min} / \mathrm{mg}$ protein.

D-amino acid oxidase [1.4.3.3] activity was measured as described by Lichtenberg and Wellner, 1968. One-tenth unit of activity yields an absorbency of 0.180 at $1=300 \mathrm{~nm}$.

Isocitric lyase [4.1.3.1] activity was measured as described by Daron and Gunsalus, 1962. One unit is defined as that amount of enzyme catalyzing the formation of $1 \mathrm{mmol}$ of glyoxylate in 5 minutes at $28^{\circ} \mathrm{C}$, at $\mathrm{pH}$ 6.0.

\section{Analysis of glucose}

Glucose was determined by the method of Somogy, 1952 and Nelson, 1944.

\section{Cell dry weight estimation}

Cell dry weight was determined gravimetrically after drying washed cells to constant weight at $105^{\circ} \mathrm{C}$.

\section{Determination of kinetic parameters}

Growth yield (Ys) was calculated as described by Pirt, 1975.

\section{Protein determination}

Protein content was determined by the method of Lowry et al. 1951. Bovine serum albumin (Sigma-Aldrich Chemie $\mathrm{GmbH}$, Germany) was used as a standard. 
Table 1. Catalase and $\mathrm{Cu} / \mathrm{Zn}$ superoxide dismutase activities of cell-free extract, obtained from strains NBIMCC 582 , NBIMCC 583 and NBIMCC 584 during cultivation in YPD medium.

\begin{tabular}{|l|c|c|c|c|c|c|}
\hline \multicolumn{1}{|r|}{ Enzyme activities } & \multicolumn{2}{|c|}{ Catalase activity D E/min/mg protein } & \multicolumn{2}{c|}{ Cu/Zn SOD activity U/mg protein } \\
\hline Cultivation on YPD medium & NBIMCC 582 & NBIMCC 583 & NBIMCC 584 & NBIMCC 582 & NBIMCC 583 & NBIMCC 584 \\
\hline 12 h of cultivation & $0.35 \pm 0.02$ & $0.80 \pm 0.01$ & $0.45 \pm 0.01$ & $5.72 \pm 0.01$ & $3.56 \pm 0.01$ & $4.19 \pm 0.016$ \\
\hline 48 h of cultivation & $6.56 \pm 0.011$ & $10.90 \pm 0.017$ & $7.34 \pm 0.011$ & $9.16 \pm 0.015$ & $6.97 \pm 0.02$ & $7.48 \pm 0.022$ \\
\hline 72 h of cultivation & $4.05 \pm 0.01$ & $4.28 \pm 0.014$ & $4.15 \pm 0.011$ & $2.57 \pm 0.03$ & $2.94 \pm 0.01$ & $2.85 \pm 0.01$ \\
\hline
\end{tabular}

\section{Polyacrylamide gel electrophoresis}

PAGE was performed on $10 \%$ resolving and $3.5 \%$ stacking gels according to Davis, 1964 on vertical electrophoretic unit (Mighty Small II Hoeferâ, Amersham Pharmacia Biotech).

Catalase activity was visualized by incubating the gels in solution, containing $0.15 \mathrm{M} \mathrm{NaSO}$ and $0.3 \mathrm{M} \mathrm{H} \mathrm{H}_{2}$ for 15 min at room temperature, followed by brief rinsing with distilled water and further treatment with iodine solution (\% KI and \% b). As a result dark blue bands of catalase activity on pale-blue background appeared.

Peroxidase activity on acrylamide gel was developed using the method of Selander et al. 1986.

Determination of charge isomers was performed following the methodology of Hedrick and Smith, 1968.

Molecular weight determination of mitochondrial catalase was performed on $10 \%$ PAGE. As standard, proteins with known molecular weight - thyroglobulin 669 000, ferritin 440000 , catalase 232000 , lactate dehydrogenase 140000 , bovine serum albumin 67000 (HMW Native, Amersham Pharmacia Biotech), stained with Coumassi blue were used. The HRm values of molecular markers were plotted against their molecular weight and equation, describing the curve was drawn. The molecular weight of the mitochondrial catalase was calculated, using the obtained equation.

\section{Results and Discusión}

\section{Catalase activity and electrophoretic profile of the enzyme}

The catalase enzyme has been investigated during cultivation of Saccharomyces cerevisiae NBIMCC 582, NBIMCC 583 and NBIMCC 584 strains on YPD medium containing $2 \%$ glucose, which is widely used in yeast studies and provides comprehensive experiences on this enzyme (Cross and Ruis, 1978; Traczyk et al. 1985;
Skoneczny and Rytka, 2000). Growth of the strains has been performed for $72 \mathrm{~h}$ and samples have been withdrawn during exponential and stationary phase of the culture in order to determine cell dry weight and glucose consumption Figure $1 \mathrm{a}, \mathrm{b}, \mathrm{c}$ ) It is evident that a diauxic growth takes place as glucose is exhausted at the 12th hour of cultivation. High yield coefficient $Y s$ is obtained $(0,415 \pm 0,018-0,423$ $\pm 0,010)$. The complex nutrient medium YPD, containing organic compounds available from yeast extract and bactopeptone caused this increase in the value of $\mathrm{Ys}$ in comparison to those predicted for growth of Saccharomyces cerevisiae on glucose (Walker, 1998). Samples of biomass have been processed and crude enzyme extracts have been prepared. A spectrophotometrical analysis of the total catalase activity at different hours of growth of the strains is shown in Table 1. The highest catalase activity was measured after $48 \mathrm{~h}$ of cultivation, which coincided, with the exponential growth phase of the cultures, after the diauxic pattern of the growth curves. This increase in catalase activity after the exhaustion of glucose in the nutrient medium could be due to the availability of different amino compounds in YPD medium, which are metabolized by fungi through hydrogen producing oxidase (Zwart et al. 1980). A correlation of the catalase activity with the accumulation of its specific substrate $\left(\mathrm{H}_{2} \mathrm{O}_{2}\right)$ obviously takes place.

An electrophoretic analysis of the crude extracts obtained from cells of Saccharomyces cerevisiae NBIMCC 583 strain of different physiological state is shown in Figure 2. After 6 hours growth, a single catalase band with Rm of 0,257 has been visualized. The next electrophoretic analyses of catalase have been performed at 12, 48 and 72 hours of cultivation, when glucose from the nutrient medium has been thoroughly consumed. An interesting fact is the appearance of a second band with $\mathrm{Rm} 0,218$ at 12 and 48 hours of cultivation and its disappearance at $72 \mathrm{~h}$. The catalase band, present during all cultivation period is with $\mathrm{Rm}$ value of 0,257 . 
Table 2. Determination of purity of mitochondrial fractions, obtained from Saccharomyces cerevisiae strains NBIMCC 582, NBIMCC 583 and NBIMCC 584 trough measurement specific activities of cytosolic ${ }^{1}$, peroxisomal ${ }^{2}$ and mitochondrial ${ }^{3}$ marker enzymes.

\begin{tabular}{|c|c|c|c|c|c|c|}
\hline Strains & NBIMCC 582 & NBIMCC 583 & NBIMCC 584 & NBIMCC 582 & NBIMCC 583 & NBIMCC 584 \\
\hline Enzyme activities & \multicolumn{3}{|c|}{ Mitochondrial fraction } & \multicolumn{3}{|c|}{ Cell free extract } \\
\hline $\begin{array}{l}\text { Catalase } \\
{[\text { E/min/mg protein }]}\end{array}$ & $5.3 \pm 0.3$ & $6.8 \pm 0.2$ & $5.5 \pm 0.1$ & $6.6 \pm 0.3$ & $10.9 \pm 0.4$ & $7.34 \pm 0.3$ \\
\hline $\begin{array}{l}\text { Peroxidase } \\
\text { [E/min/mg protein }]\end{array}$ & $0.17 \pm 0.01$ & $0.18 \pm 0.01$ & $0.16 \pm 0.02$ & $0.02 \pm 0.01$ & $0.02 \pm 0.012$ & $0.03 \pm 0.014$ \\
\hline $\begin{array}{l}\text { Glucose-6 phosphate } \\
\text { dehydrogenase } \\
\text { [mU/mg protein] }\end{array}$ & None & None & None & $14.16 \pm 0.02$ & $18.74 \pm 0.05$ & $19.04 \pm 0.02$ \\
\hline $\begin{array}{l}\text { Hexokinase }^{1} \\
{[\mathrm{~mol} / \mathrm{min} / \mathrm{mg} \text { protein] }}\end{array}$ & None & None & None & $0.020 \pm 0.010$ & $0.025 \pm 0.002$ & $0.020 \pm 0.015$ \\
\hline $\begin{array}{l}\text { D aminoacid oxidase }{ }^{2} \\
{[\mathrm{U} / \mathrm{mg} \text { protein] }}\end{array}$ & None & None & None & $0.058 \pm 0.001$ & $0,108 \pm 0.001$ & $0,076 \pm 0.001$ \\
\hline $\begin{array}{l}\text { Isocitric lyase }^{2} \\
{[\mathrm{U} / \mathrm{mg} \text { protein] }}\end{array}$ & None & None & None & $0.102 \pm 0.013$ & $0.098 \pm 0.023$ & $0.108 \pm 0.015$ \\
\hline $\begin{array}{l}\text { Succinate } \\
\text { dehydrogenase }{ }^{3} \\
{[\mathrm{~mol} / \mathrm{min} / \mathrm{mg} \text { protein] }}\end{array}$ & $0.14 \pm 0.01$ & $0.18 \pm 0.01$ & $0.15 \pm 0.01$ & $0.014 \pm 0.002$ & $0.016 \pm 0.0012$ & $0.014 \pm 0.009$ \\
\hline $\begin{array}{l}\text { Mn SOD } \\
{[\mathrm{U} / \mathrm{mg} \text { protein }]^{3}}\end{array}$ & $19.52 \pm 0.050$ & $16.89 \pm 0.042$ & $17.28 \pm 0.032$ & $8.42 \pm 0.012$ & $6.33 \pm 0.044$ & $6.80 \pm 0.010$ \\
\hline
\end{tabular}

These observations are in agreement with the data published by Izawa et al. 1996 for catalase A and catalase T deficient mutants of Saccharomyces cerevisiae. They showed electrophoretic profile of the two types of catalases where the $\mathrm{Rm}$ value of catalase $\mathrm{A}$ is lower than that of catalase $\mathrm{T}$. Therefore, in our experiment the protein band with $\mathrm{Rm} 0.218$ corresponds to catalase $\mathrm{A}$ and that with $\mathrm{Rm}$ 0.257 - to catalase T. Catalase $\mathrm{T}$ we found active during the whole cultivation period. These results clearly showed that the active catalase $\mathrm{A}$ is synthesized after complete utilization of glucose, when catabolite repression disappeared (Cross and Ruis, 1978). During stationary phase of the culture $(72 \mathrm{~h})$ when catalase A was not observed, obviously a degradation of peroxisomes and lysis of the proteins took place. The above mentioned two catalase enzymes act in the cells of Saccharomyces cerevisiae, decomposing $\mathrm{H}_{2} \mathrm{O}_{2}$ accumulated during oxidative processes in the cytosole and correlating with the $\mathrm{Cu} / \mathrm{Zn}$ superoxide dismutase activity (measured after inhibition of $\mathrm{Mn}$ SOD) Table 1 . There is not clear evidence about such kind of mechanism placed in mitochondria and coupling with $\mathrm{Mn}$ SOD. The role of $\mathrm{H}_{2} \mathrm{O}_{2}$ scavenging enzymes in those organelles is predicted within cytochemical experiments with cells of Saccharomyces cerevisiae by Hoffman et al. 1970. They found positive DAB reaction of intracristate space of mitochondria in the late exponential phase. These results are inconclusive due to the lack of specificity of DAB staining technique. The last could be oxidized to chromophore in the presence of $\mathrm{H}_{2} \mathrm{O}_{2}$ by diverse hemeproteins, including mitochondrial cytochromes (Seligman et al. 1968). This nonspecificity of the above mentioned reaction is proved also by DAB staining in catalase deficient mutant Trypanosoma cruzi (Decampo et al. 1976). Thus, clear understanding for the mitochondrial $\mathrm{H}_{2} \mathrm{O}_{2}$ decomposing mechanism in yeast is still lacking.

\section{Investigation of mitochondrial fraction for catalase}

Isolated mitochondrial fractions from Saccharomyces cerevisiae strains were tested for purity using measurement of the activities of several enzymes, typically located in different cellular compartments: hexokinase and glucose-6phosphate dehydrogenase - in cytosole, D-amino oxidase and isocitric lyase - in peroxisomes and succinate dehydrogenase and Mn superoxide dismutase - in mitochondria. Results are presented in Table 2. Using these marker enzymes the purity of mitochondrial fraction was displayed, as the enzyme activities characteristic for the 
cytosole and the peroxisomes were not detected in it. The values found for the activity of succinate dehydrogenase and Mn superoxide dismutase were typical for the mitochondrial fraction, which proved that it is a pure one. Then, the specific activities of catalase and peroxidase enzymes were determined. They are $5.3-6.8 \mathrm{D} \mathrm{E} / \mathrm{min} / \mathrm{mg}$ protein for the catalase and $0.16-0.18 \mathrm{DE} / \mathrm{min} / \mathrm{mg}$ protein for the peroxidase (Table 2). Further the mitochondrial fractions and crude extracts obtained from strains 582, 583 and 584 were subjected to $10 \%$ acrylamide gel electrophoresis. The results obtained are presented in Figure $3 \mathrm{a}, \mathrm{b}, \mathrm{c}$ All mitochondrial fractions contained a single band specifically stained for catalase. At the same time the visualization of the peroxidase activity was not ,probably due to very low activity of the protein (Figure 4). The low peroxidase activity, measured spectrophotometrically, could be due to some kind of peroxidase activity of the catalase, as it has been shown for Candida boidinii (Ueda et al. 1990). The results obtained for the mitochondrial catalase in the three strains clearly indicated that a catalase enzyme located in the mitochondria of Saccharomyces cerevisiae exists. The Rm value of the enzyme pattern is 0.239 for the three strains. From the data presented in Figure 3, it is evident that for all strains studied, the electrophoretic pattern of the mitochondrial catalase is different from the known profile for these enzymes in Saccharomyces cerevisiae (Traczyk et al. 1985; Izawa et al. 1996). Obviously the concentrations of this protein in the total cell-free extract, where catalase A and $\mathrm{T}$ has been found, is very low and its visualization becomes possible after is olation of pure mitochondrial fraction. Its availability in three different strains of Saccharomyces cerevisiae indicated that it is their common feature.

\section{Evidence for correlation of mitochondrial catalase with Mn superoxide dismutase activity}

It is well known that catalase and $\mathrm{Cu} / \mathrm{Zn}$ superoxide dismutase activities correlate during cultivation of many yeasts on different substrates and conditions (KujumdzievaSavova et al. 1991; Costa et al. 1993). It is worthwhile to study the activity of mitochondrial catalase, Mn and intercristate $\mathrm{Cu} / \mathrm{Zn}$ superoxide dismutase enzymes in correlation with growth. These investigations were performed with the three Saccharomyces cerevisiae strains 582, 583 and 584 using the mitochondrial fraction obtained from different hours of cultivation. The dynamics of above mentioned enzyme activities are presented in Figure $5 \mathrm{a}, \mathrm{b}$, c. These data clearly showed that the specific activities of catalase and Mn superoxide dismutase enzymes correlated with the growth and their maximum has been measured at $48 \mathrm{~h}$ of cultivation. The activity of $\mathrm{Cu} / \mathrm{Zn}$ mitochondrial superoxide dismutase appears to be a constant one $(3.5 \pm$ $0.02 \div 5.0 \pm 0.01 \mathrm{U} / \mathrm{mg})$ during the whole period of cultivation.

These results suggested that the role of mitochondrial catalase is coupled mainly with the function of manganese superoxide dismutase for detoxification of mitochondria from reactive oxygen species, generated during respiratory processes within these organelles. The presence of low peroxidase activity indicated that it also takes part in this reaction of the cells as an additional mechanism. Evidently enzymes catalase and superoxide dismutase play the basic detoxifying function in the mitochondria.

High activity of antioxidant enzymes found during cultivation on YPD medium in spite of the presence of glucose as a carbon source indicated that a respiratory metabolism also takes place, because of the formation of ethanol (Walker, 1998). It is well known that Saccharomyces cerevisiae utilize glucose in aerobic conditions mainly fermentatively (Kappeli, 1986), but the diauxic growth and high values of Ys showed that utilization of additional growth substrates likely occurred.

\section{Determination of charge and molecular weight of Saccharomyces cerevisiae mitochondrial catalase}

The native PAGE method developed by Hedrick and Smith, 1968 provides site estimation for proteins analyzed on gels of successive high acrylamide concentration. As it has been mentioned above, the nolecular weight of catalase $\mathrm{T}$ is between 225 - $250 \mathrm{kD}$, and for catalase A - considerably lower 170 - $190 \mathrm{kD}$. The electrophoretic pattern shows abnormal mobility of both cytosolic catalase enzymes. Applying the method of Hedrick and Smith, 1968, investigation of their behavior in native PAGE with different concentrations of acrylamide was performed (Figure 6. The results obtained Figure 6 and Figure 7) suggest that both enzymes are charge isomers which explains why catalase A, although with lower molecular weight possess lower Rm value than catalase T. Evaluating the plot of Rm, the mitochondrial enzyme could be also considered as charge isomer. For estimation the molecular weight of the mitochondrial enzyme, comparison of its relative mobility with the ones of known proteins was done Figure 8) Plotting the HRm against molecular weight values of the markers allowed drawing an equation, describing the electrophoretic profile Figure 9. On this basis we could calculate the MW of the mt enzyme, which is approximately $240000 \mathrm{Da}$.

These data open the question about the origin of this new catalase protein, located in the mitochondria and its relationship to catalases $\mathrm{A}$ and $\mathrm{T}$.

\section{References}

AEBI, H. Oxydasen und reductasen. In: BERGEMEYER H.V., ed. Methoden der Enzymatishen Analys. Berlin, Acad. Verl., 1970, p. 636-641.

BEAUCHAMP, C. and FRIDOVICH, I. Superoxide dismutase: improved assays and an assay applicable to acrylamide gels. Analytical Biochemistry, October 1971, vol. 44, no. 1, p. 276-287. 
BONNER, W.D. Enzymes of Citric Acid Cycle. In: Colowich S.P. and Kaplan N.O., eds. Methods in enzymology, Academic Press Inc., New York, USA, 1955, vol. 1, p. 722-729.

CHARIZANIS, C.; JUHNKE, H.; KREMS, B. and ENTIAN, K.D. The mitochondrial cytochrome c peroxidase Ccp1 of Saccharomyces cerevisiae is involved in conveying an oxidative stress signal to the transcription factor Pos9 (Skn7). Molecular and General Genetics, October 1999, vol. 262, no. 3, p. 437-447.

COSTA, Vitor; REIS, Eduardo; QUINTANILHA, Alexandre and MORADAS-FERREIRA, Pedro. Acquisition of ethanol tolerance in Saccharomyces cerevisiae: the key role of the mitochondrial superoxide dismutase. Archives in Biochemistry and Biophysics, February 1993, vol. 300, no. 2, p. 608-614.

CROSS, S.H. and RUIS, H. Regulation of catalase synthesis in Saccharomyces cerevisiae by carbon catabolite repression. Molecular and General Genetics, October 1978, vol. 166 , no. 1, p. 37-43.

DARON, H.H. and GUNSALUS, I.G. Enzymes of citric acid cycle. In: COLOWICK, S.P. and KAPLAN, N.O., eds. Methods in enzymology. Academic Press Inc., New York, USA, 1962, vol. 5, p. 628-630. ISBN-0-12-182005-X.

DAVIS, B.J. Disc electrophoresis II. Methods and application to human and serum proteins. Annual New York Academic Science, 1964, vol. 121, p. 404-427.

DECAMPO, R.; DE BOISO, J.F.; BOVERIS, A. and STOPPANI, A.O.M. Localization of peroxidase activity in Trypanozoma cruzi microbodies. Experientia, August 1976, vol. 32 , no. 8 , p. $971-975$.

DEFONTAINE, Alaine; LECOCQ, Michele F. and HALLET, Jean-Noel. A rapid miniprep method for the preparation of yeast mitochondrial DNA. Nucleic Acids Rsearch, November 1991, vol. 19, no. 1, p. 185.

ESTRUCH, Francisco. Stress-controled transcription factors, stress-induced genes and stress tolerance in budding yeast. FEMS Microbiology Reviews, October 2000, vol. 24 , no. 4 , p. 469-486.

GELLER, B.L. and WINGE, D.R. Oxygen radicals in biological systems. In: PACKER, L., ed. Methods of Enzymology. Orlando, Academic Press Inc., 1984, vol. 5, p. 105-109.

GREENE, G.L. Enzymes of glucose catabolism pathways in Colletotrichum and Gleosporium. Mycologia, May 1969, vol. 61 , no. 5 , p. 902-914.

HEDRICK, J.L. and SMITH, A.J. Size and charge separation and estimation of molecular weights of proteins by disc gel electophoresis. Archives in Biochemistry and Biophysics, July 1968, vol. 126, no. 1, p. 155-164.

HOFFMAN, H.P.; SZABO, A. and AVERS, C.J. Cytochemical localisation of catalase activity in yeast peroxisomes. Journal of Bacteriology, October 1970, vol. 104, no.1, p. 581-584.

HOLTTA, Fkki. Oxidation of spermidine and spermine in rat liver: Purification and properties of polyamine oxidase. Biochemistry, January 1977, vol. 16, no. 1, p. 91-100.

IZAWA, Shingo, INOUE, Yoshiharu and KIMURA, Akira. Importance of catalase in the adaptive response to hydrogen peroxide: analysis of acatalasaemic Saccharomyces cerevisiae. Biochemistry Journal, November 1996, vol. 320, no. 1, p. 61-67.

JAMIESON, D.J. The effects of oxidative stress on Saccharomyces cerevisiae. Redox Report, January 1995, vol. 1, no. 1, p. 89-95.

KAPPELI, O. Regulation of carbon metabolism in Saccharomyces cerevisiae and related yeasts. In: ROSE, A.H. and TEMPEST D.W., eds. Advances in Microbial Physiology. London, Academic Press Inc., 1986, vol. 28, p. 181-209. ISBN-0-120-27728-X.

KLEI, Ida J.; RYTKA, Joanna; KUNAU, Wolf H. and VEENHIUS, Marten. Growth of catalase A and catalase T deficient mutant strains of Saccharomyces cerevisiae on ethanol and oleic acid. Archives in Microbiology, January 1990, vol. 153, p. 513-517.

KOWALTOWSKI, Alicia J.; ROGER, Castilho F. and VERCESI, Anibal E. Mitochondrial permeability transition and oxidative stress. FEBS Letters, March 2001, vol. 495, p. $12-15$.

KUJUMDZIEVA-SAVOVA, V.; SAVOV, A. and GEORGIEVA, E.I. Role of superoxide dismutase in the oxidation of n-alkanes by yeast. Free Radicals in Biology and Medicine, February 1991, vol. 11, no. 3, p. 263-268.

LAPINSKAS, P.; RUIS, H. and CULOTTA, V. Regulation of Saccharomyces cerevisiae catalase gene expression by copper. Current Genetics, November 1993, vol. 24, no. 5, p. 388-393.

LICHTENBERG, L.A. and WELLNER, D. Amino acid oxidation and racemization. In: TABOR, L.A. and TABOR, C.W., eds. Methods in enzymology, Academic Press Inc., New York, USA, 1971, Vol. XVII B, P. 593-595, ISBN-0121-818772.

LOWRY, O.H.; ROSENBROUGH, N.J.; FARR, O.L. and RANDLE, R.J. Protein measurement with the Folin phenol 
reagent. Journal of Biological Chemistry, February 1951, vol. 193, no. 2, p. 265-275.

NELSON, N. A photometric adaptation of the Somogy method for the determination of glucose. Journal of Biological Chemistry, February 1944, vol. 153, no. 3, p. 375-379.

PIRT, S.H. Principles of Microbe and Cell Cultivation. Blackwell Scientific Publications, Oxford, 1975, ISBN-0470-690380.

RADI, Rafael; TURRENS, Julio F.; CHANG, Ling Y.; BUSH, Kenneth M.; CRAPO, James D. and FREEMAN, Bruce A. Detection of catalase in rat heart mitochondria. Journal of Biological Chemistry, November 1991, vol. 266, no. 32 , p. 22028-22034.

RAVINDRANATH, S.D. and FRIDOVICH, I. Isolation and characterization of a manganese-containing superoxide dismutase from yeast. Journal of Biological Chemistry, August 1975, vol. 250, no. 15, p. 6107-6112.

SCANDALIOS, J.G.; TONG, W.F. and ROUPAKIAS, D.G. Cat3I, a third gene locus coding for a tissue specific catalase in maize: genetics, intracellular location, and some biochemical properties. Molecular and General Genetics, January 1980, vol. 179, no. 1, p. 33-41.

SEAH, Tony C.M.; BHATTI, A. and KAPLAN, Gordin J. Novel catalytic proteins of baker's yeast. An atypical catalase. Canadian Journal of Biochemistry, November 1973, vol. 51, no. 11, p. 1551-1555.

SELANDER, Robert K.; CAUGANT, Dominique A.; OCHMAN, Howerd; MUSSER, James M.; GILMOUR, Marion N. and WHITTAM, Thomas S. Methods of multilocus enzyme electrophoresis for bacterial population genetics and systematics. Applied and Environmental Microbiology, May 1986, vol. 51, no. 5, p. 873-884.

SELIGMAN, A.M.; KARNOVSKY, M.J.; WASSEWEKRUG, H.L. and HANKER, J.S. Nondroplet ultraestructural demonstration of cytochane oxidase acticity with a polymerizing osmiophilic reagent, diaminobenzidine (DAB). Journal of Cell Biology, July 1968, vol. 38, no.1, p. 1-14.

SKONECZNY, Marek and RYTKA, Joanna. Oxygen and haem regulate the synthesis of peroxisomal proteins: catalase A, acyl-CoA oxidase and Pex $1 \mathrm{p}$ in the yeast Saccharomyces cerevisiae; the regulation of these proteins by oxygen is not mediated by haem. Biochemistry Journal, August 2000, vol. 350, no. 1, p. 313-319.

SOMOGY, M. Notes on sugar determination. Journal of Biological Chemistry, January 1952, vol. 195, p. 19-23.

STURTZ, L.A.; DIEKERT, K.; JENSEN, L.T.; LILL, R. and CULOTTA, V.C. A fraction of the yeast $\mathrm{Cu} / \mathrm{Zn}$ superoxide dismutase and its metallochaperone, CCS, localise to the intermembrane space of mitochondria: a physiological role for SOD1 in guarding against mitochondrial oxidative damage. Journal of Biological Chemistry, October 2001, vol. 276, no. 41, p. 38084-38089.

TRACZYK, Aleksandra; BILINSKI, Tomasz; LITWINSKA, Jadwiga; SKONECZNY, Marek and RYTKA, Joanna. Catalase $\mathrm{T}$ defecient mutants of Saccharomyces cerevisiae. Acta Microbiologica Polonica, February 1985, vol. 34, no. 3-4, p. 231-241.

UEDA, Mitsuyoshi; MOZAFFAR, Sabiha and TANAKA, Atsuo. Catalase from Candida boidinii 2201. Hydrocarbons and Methylotrophy, In: LIDSTORM, Marry, ed. Methods in Enzymology, 1990, vol. 188, p. 463-467. ISBN-0-12182005-X.

VERDUYN, Cornelis; GUISEPPIN, Marco L.F.; SCHEFFERS, Alexander $\mathrm{W}$. and DIJKEN, Johannes P. Hydrogen peroxide metabolism in yeast. Applied and Environmental Microbiology, August 1988, vol. 54, no. 8, p. 2086-2090.

WALKER, G.M. Yeast Physiology and Biotechnology. New York, John Wiley and Sons, 1998, p. 362. ISBN-0471-964468.

ZWART, K.; VEENHIUS, M.; DIJKEN, J.P. andHARDER, W. Development of amino oxidase containing peroxisomes in yeasts during growth on glucose in the presence of methylamine as a sole source of nitrogen. Archives in Microbiology, June 1980, vol. 126, no. 2, p. 117-126.

Note: EJB Electronic Journal of Biotechnology is not responsible if on-line references cited on manuscripts are not available any more after the date of publication. 


\section{APPENDIX}

Figures
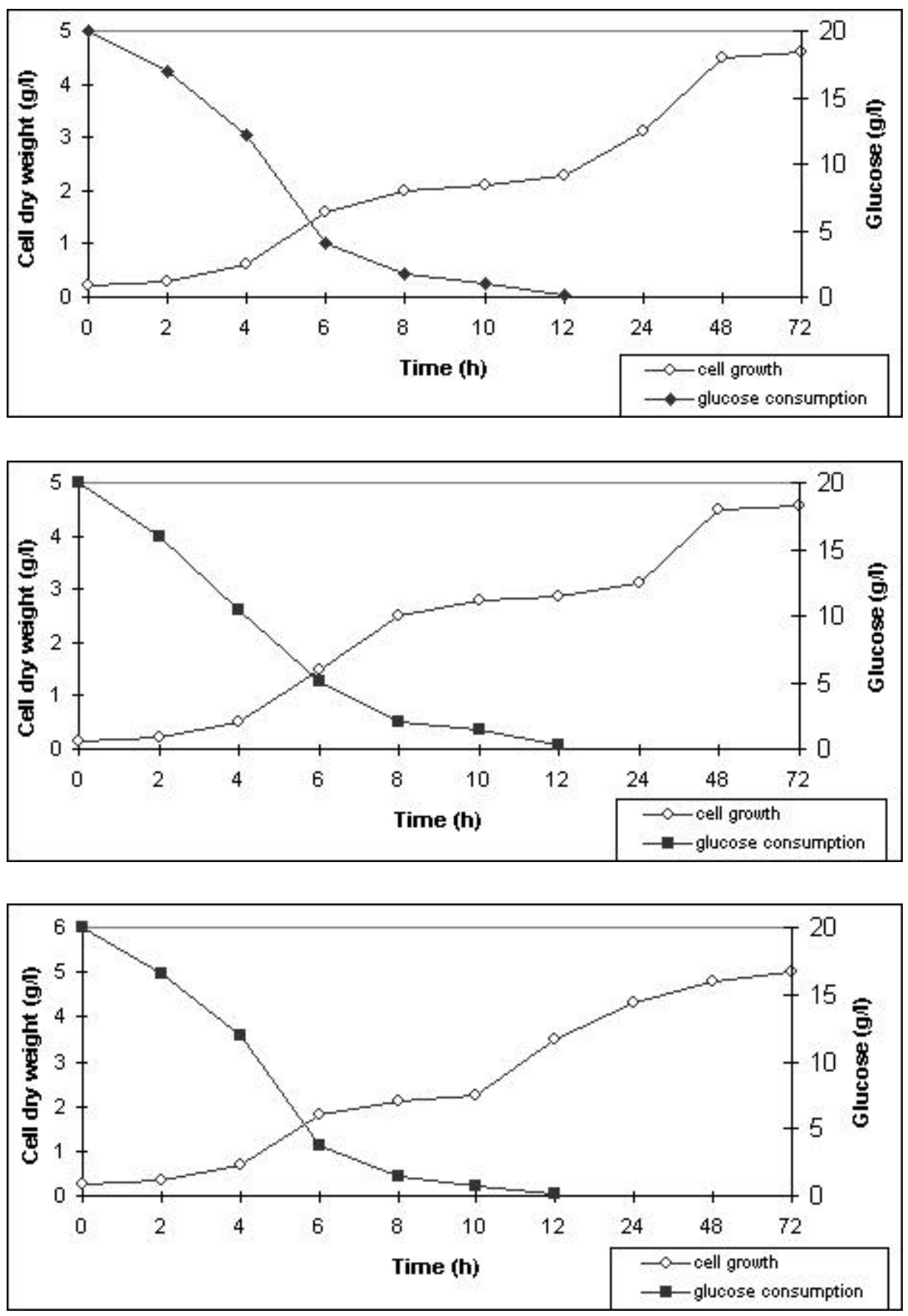

Figure 1. Growth curve and glucose consumption after cultivation of Saccharomyces cerevisiae in YPD medium:
a. strain NBIMCC 582;
b. strain NBIMCC 583;
c. strain NBIMCC 584. 


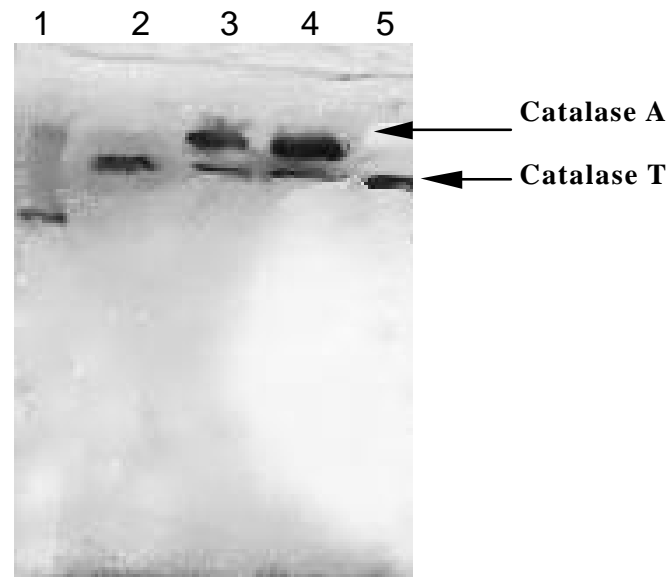

Figure 2. The pattern of catalase activity in YPD medium at different hours of cultivation.

Lane 1. Catalase marker enzyme (Merck KgaA, Darnstadt, Germany );

Lane 2. At 6 h of cultivation;

Lane 3. At $12 \mathrm{~h}$ of cultivation, at $48 \mathrm{~h}$ of cultivation, at $72 \mathrm{~h}$ of cultivation.

Lane 4. at $48 \mathrm{~h}$ of cultivation

Lane 5. at $72 \mathrm{~h}$ of cultivation.

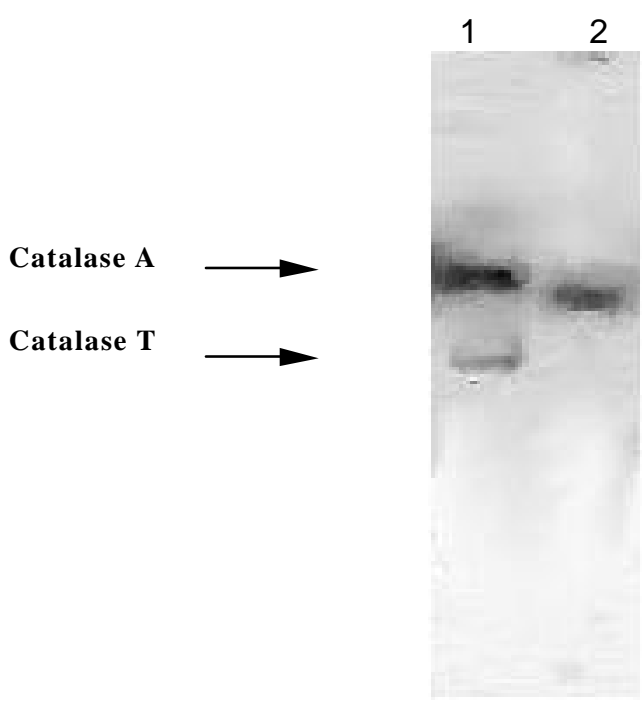

a

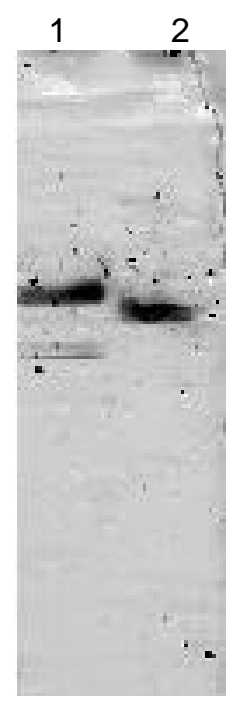

b

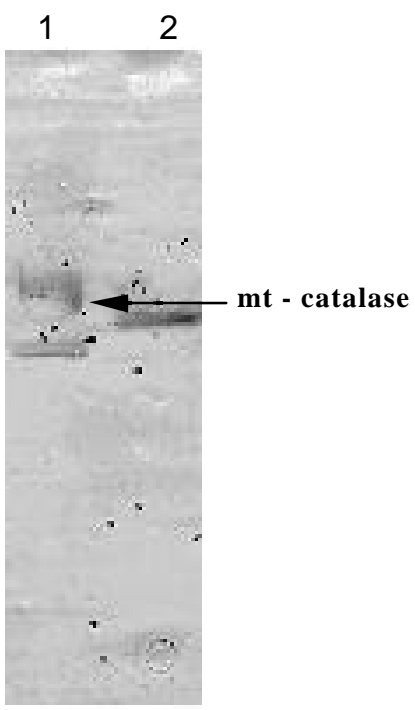

C

Figure 3. Patterns of cell-free extract (catalase $\mathbf{T}$ and catalase $\mathrm{A}$ ) and mitochondrial fraction (mt-catalase):

a. strain NBIMCC 582;

b. strain NBIMCC 583;

c. strain NBIMCC 584;

Lane 1. cell-free extract

Lane 2. $\mathrm{mt}$ - fraction. 
Kujumdzieva, A.V. et al.

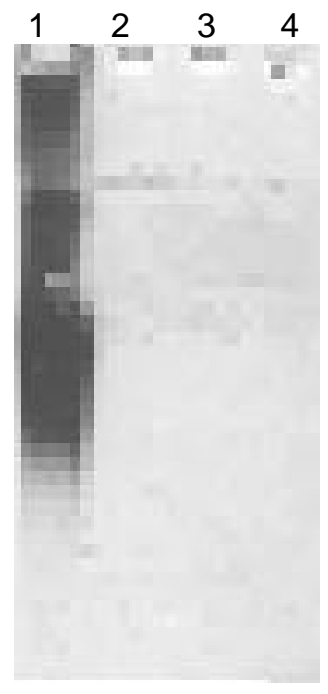

a

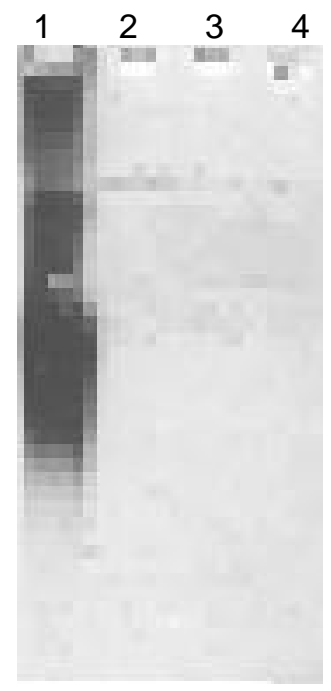

b

Figure 4. Native polyacrylamide gel electrophoresis of peroxidase activity:

a. peroxidase activity of cell-free extract;

b. peroxidase activity of mitochondrial fraction.

Lanes 1 and 5. peroxidase activity of marker enzyme (Sigma-Aldrich Chemie GmbH, Germany);

Lanes 2 and 6. peroxidase activity of strain NBIMCC 582;

Lanes 3 and 7. peroxidase activity of strain NBIMCC 583;

Lanes 4 and 8. peroxidase activity of strain NBIMCC 584.
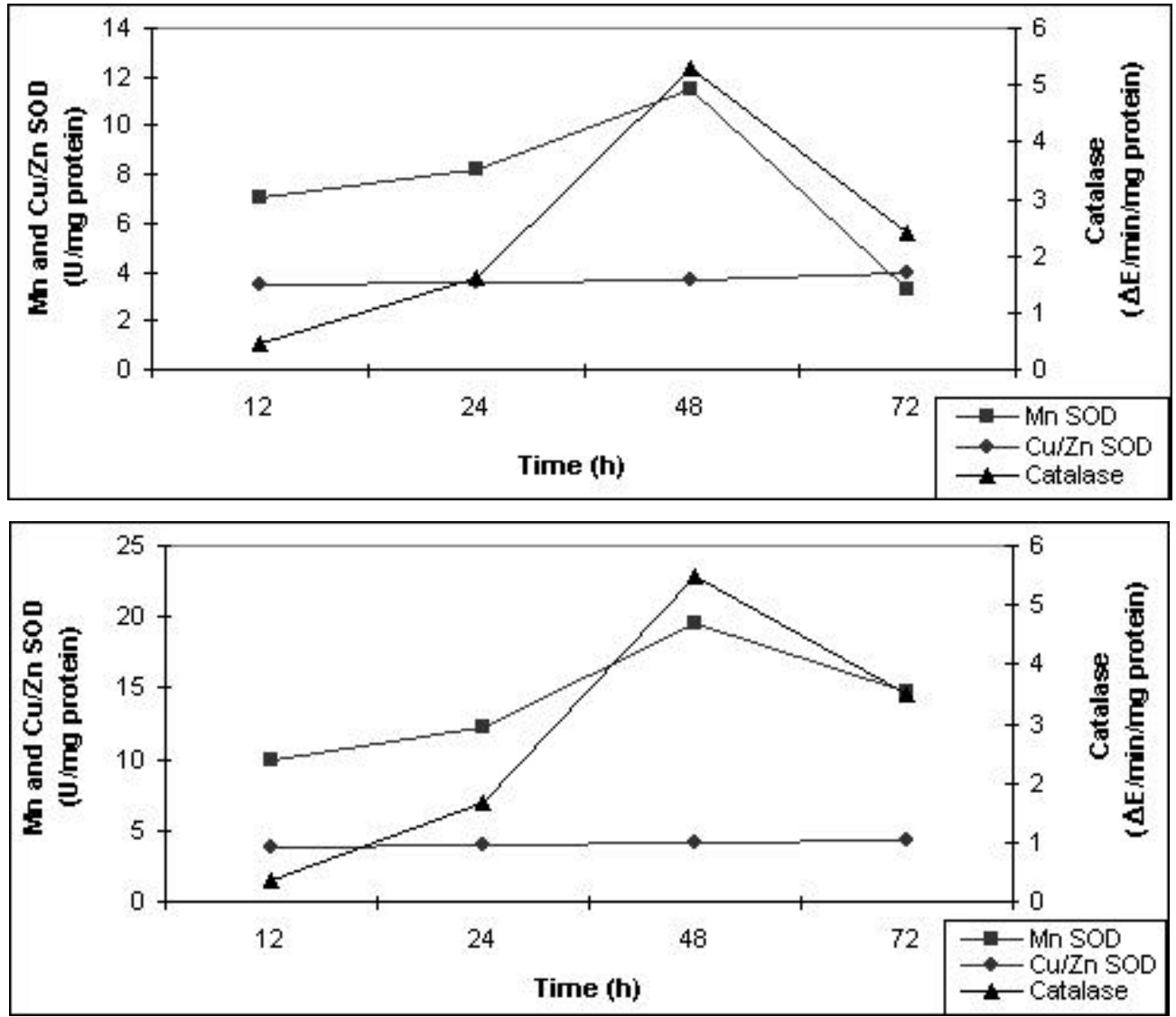


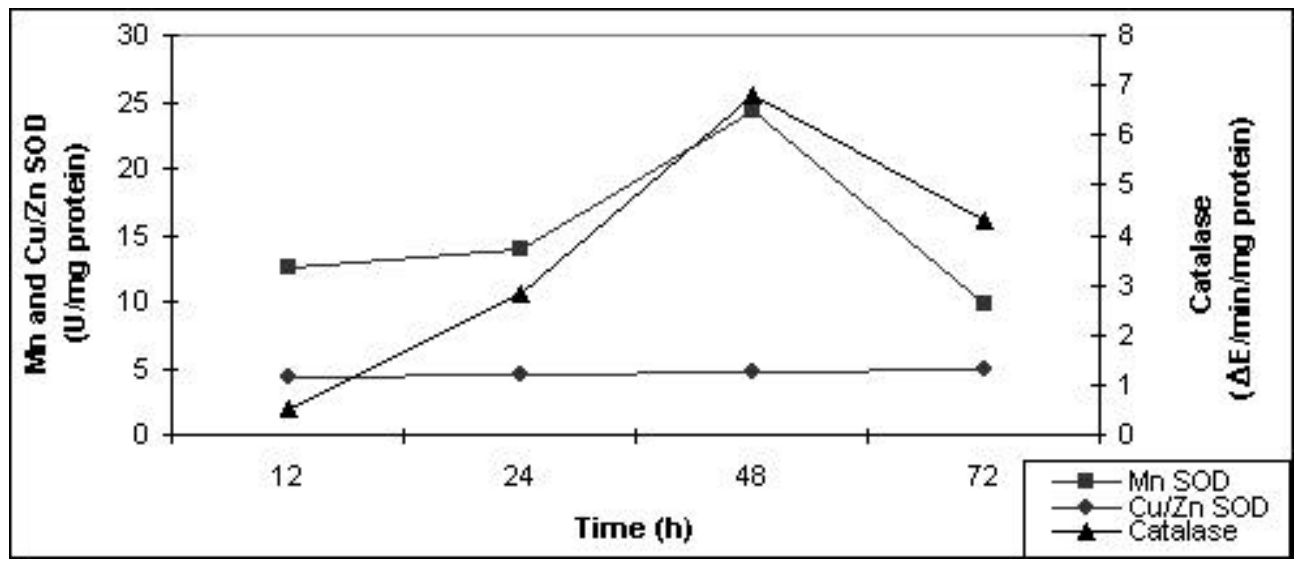

Figure 5. Activity of mitochondrial catalase, Mn SOD and Cu/Zn SOD of Saccharomyces cerevisiae during cultivation in YPD medium:
a. strain NBIMCC 582;
b. strain NBIMCC 583;
c. strain NBIMCC 584 .
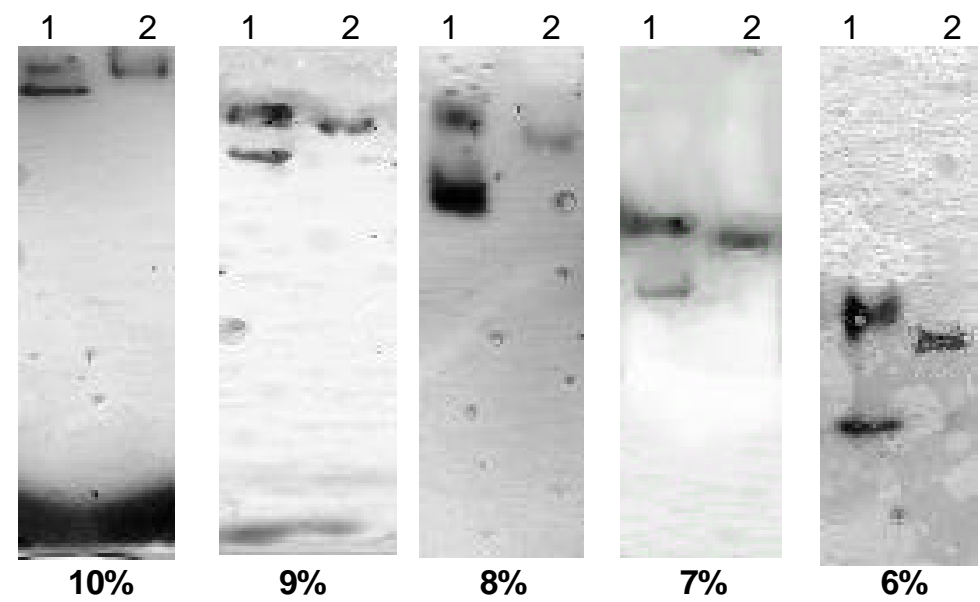

Figure 6. Effect of polyacrylamide gel concentration on the mobility of catalase enzymes of strain Saccharomyces cerevisiae NBIMCC 583:

Lane 1: cell-free extract;

Lane 2: mitochondrial fraction. 


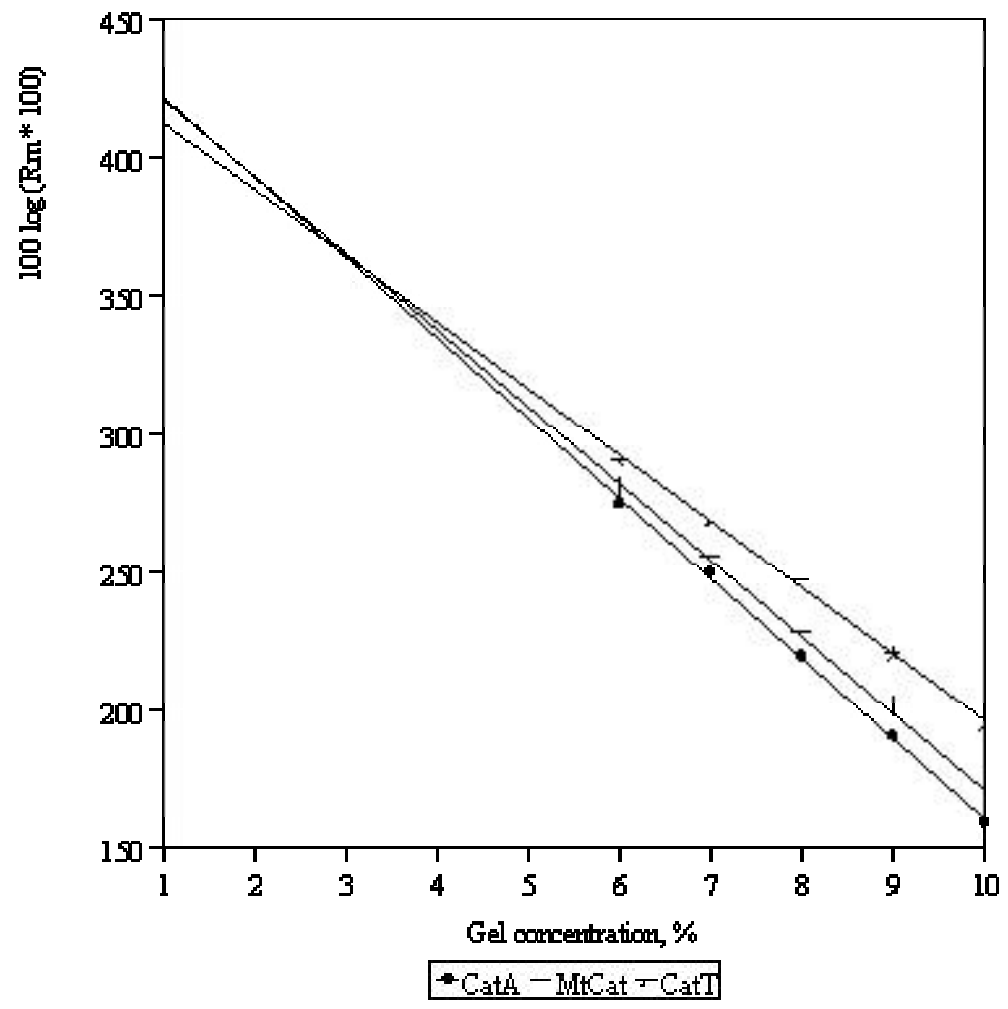

Figure 7. Catalase mobility of strain Saccharomyces cerevisiae NBIMCC 583 expressed as 100 log (100 Rm) as a function of polyacrylamide gel concentration.

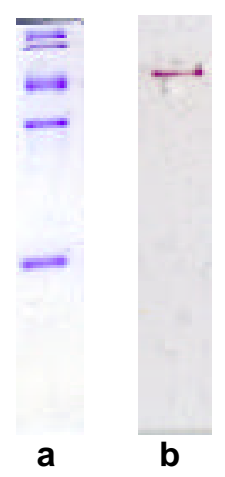

Figure 8. Determination of molecular weight of $\mathrm{mt}$ - catalase of Saccharomyces cerevisiae NBIMCC 583 by native PAGE.

a. proteins with known molecular weight (HMW Native, Amersham Pharmacia Biotech) stained with Coumassi blue bands in descending order: thyroglobulin 669 000, ferritin 440 000, catalase 232000 , lactate dehydrogenase 140000 , bovine serum albumin 67 000;

b. mt-fraction, stained specifically for catalase. 


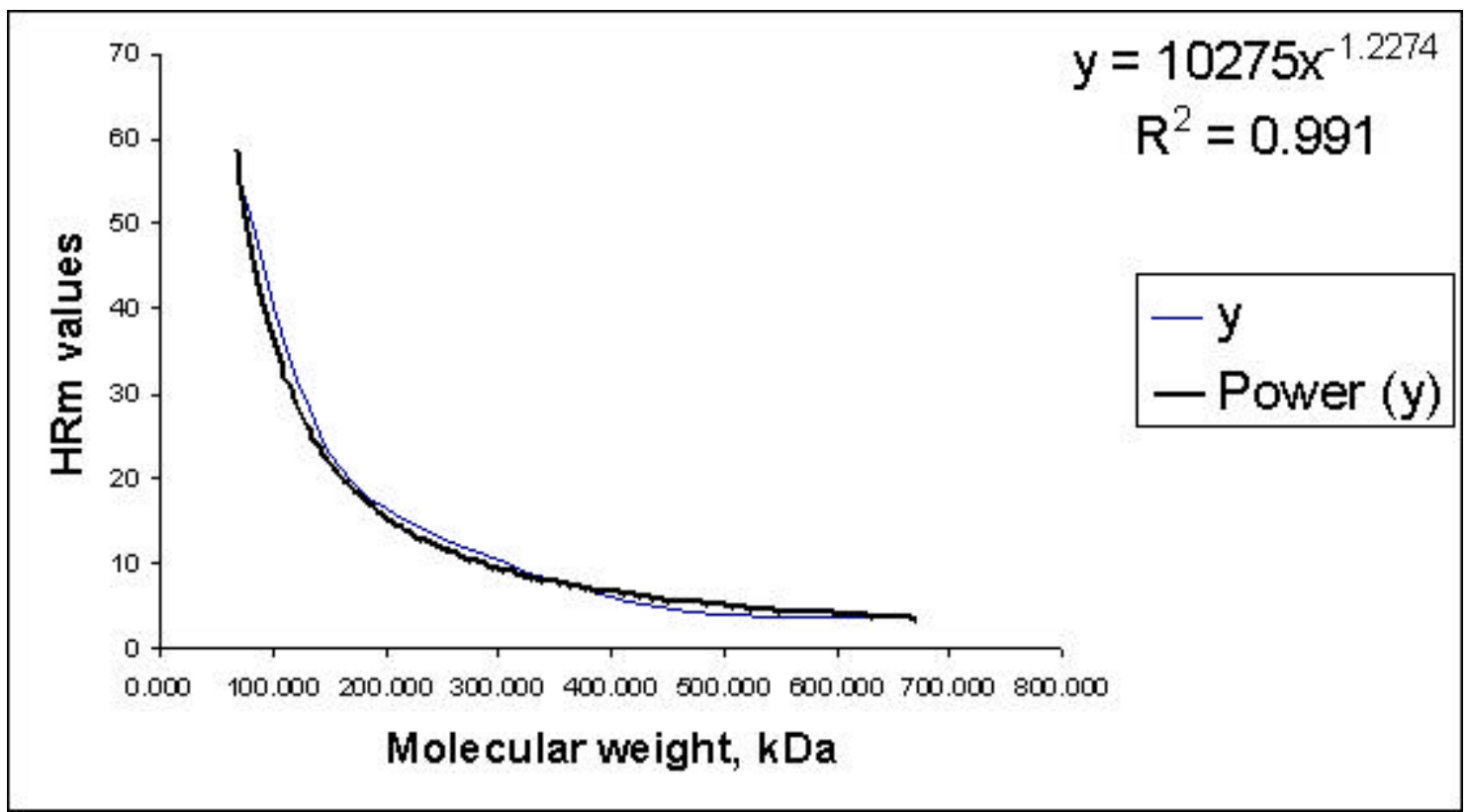

Figure 9. Dependence of HRm on molecular weight of marker proteins (HMW Native, Amersham Pharmacia Biotech) on 10\% PAGE and drawn equation, describing the curve. 